\title{
The Design of Web-Based Learning Using Google Sites for Teaching Heat and Temperature Topic
}

\author{
Raffa Fitra Ramadannisa ${ }^{\text {a) }}$ Mellyana Mega Hartina ${ }^{\text {b) }}$ \\ Physics Education Department, Faculty of Mathematics and Natural Sciences, \\ Universitas Negeri Jakarta, Rawamangun, Jakarta, 13220, Indonesia

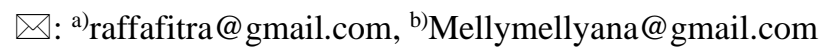

\begin{abstract}
The limited variety of learning media will create various learning problems. One of the problems that arise is the lack of motivation to learn and low learning outcomes. These problems can be overcome by developing learning media integrated with technology such as web-based learning. This study aims to produce web-based learning using Google Sites on Heat and Temperature topics for high school students. The media development used the 4D model with the following stages: 1) Define, 2) Design, 3) Develop. The design and development stages of the media involve experts who assess two aspects, namely material and media design. The average result of media expert's validation is "very feasible". The average effect of material expert validation is "feasible." Based on the validation results by experts, this media is feasible to be used as a learning medium that helps students learn Heat and Temperature topics. The weakness in this research was that the learning design on the developed media was not very relevant to the learning objectives and basic competencies. Researchers hope to develop a learning media with learning designs that are more relevant to learning objectives and basic competencies in the future.
\end{abstract}

Keywords: web-based learning, e-learning, learning media, google sites, heat and temperature

\section{INTRODUCTION}

New teachers use printed books, worksheets, OHP, blackboards, and LCDs as learning media (Januarisman \& Ghufron 2016). This raises problems related to limited resources and learning media. With limited sources and teaching media, other issues will arise, namely the low interest in learning of students. The lack of student interest in learning will lead to a common understanding and mastery of students' material. Interest in science lessons can be influenced by many factors such as classroom activities or other activities such as school level and socio-cultural context (Anderhag et al. 2015). To increase students' interest in education, they can use the teaching media. In addition, teaching media determines student learning outcomes. One of the media that can be used is website-based teaching media.

A website or site can be interpreted as a collection of pages that display text data information, still or moving image data, animation data, sound, video, and a combination of all of them, both static and dynamic, which form a series of buildings. Which are interconnected, each of which is linked to a network of pages. Web-based learning can provide broad access and opportunities for students to build their knowledge by accessing existing learning resources and media. Also, web-based learning media could improve students' learning outcomes (Orooji \& Taghiyareh 2015).

Learning using the internet is a current learning trend (Mahendra 2021). Learning using the internet can make all aspects of education adapt to the challenges of the 21 st century that require technology 
(Setyowati et al. 2020). Therefore, problems such as low learning motivation and low learning outcomes can be overcome by developing learning resources and media that utilize digital technology, such as web-based learning. The results of the questionnaire was distributed, the teachers have several obstacles in implementing web-based learning media in schools, including lack of teacher knowledge in making web-based learning media, limited funds and time, and a significant teacher workload (Januarisman \& Ghufron 2016). Several challenges make web-based learning challenging to implement in education: lack of good management, lack of funds to develop, lack of proficient information technology development, and lack of knowledge and desire of teachers to create new learning media (Halim et al. 2018).

The development of web-based learning media does not always require mastery of programming languages and requires a lot of funds. One of the pages where you can create a website easily and for free is Google Sites. Google Sites is very easy to use, primarily to support learning by maximizing Google Docs, Slides, Sheets, Forms, Youtube, Calendar, etc. Google Sites is by inserting text, images, videos, or the desired files and adjusting their position to make them look neat and selected. Learning using the Google Site provides many benefits for students and teachers, namely: learning becomes more attractive, students get teaching materials more easily and quickly, teachers have no difficulty in storing learning materials, so they are not easily lost, and teachers can give assignments through the Google Site so that students can do it directly (Azis 2019). Google Sites allows users to combine various information in one place (including videos, presentations, attachments, text, and more) that can be shared according to user needs. The use of Google Sites is free of charge and can be utilized by all users who have a google account (Taufik et al. 2018).

When using the google site (E-learning) makes students feel facilitated in the physics learning process and can help students in the learning process independently without a teacher (Lisnaeni \& Salsabila 2021). In addition, learning media using Google Sites on Sound Wave material got an average media validation score of $50.50 \%$ and a material validation of $63.50 \%$. The two average score results are included in the "appropriate" criteria (Ismawati et al. 2021). In other words, this media, according to the experts, is feasible to be used and tested on students.

Web-based learning that has been validated is feasible to use, then tested on students at school. The trial resulted in data, the website (google site) of learning Physics based on a scientific approach which was viewed from the point of view of the scientific process of students produced good and practical process skills with a percentage of $84 \%$, in terms of mastery of physics concepts students had an average score $(76 \pm 9)$. In terms of student responses, the percentage of effectiveness is $84 \%$. From these results, it can be concluded that a scientific approach-based learning website is effectively used in studying physics (Wiwin et al. 2019).

Discovery learning using personal sites (Google Sites) is an alternative method to provide meaning for education and increase student interaction with learning materials during online learning (Sarah 2020). More than $80 \%$ of students are active during learning and completing assignments. Google sites also help teachers to do more interactive learning during synchronous teaching and learning. $82 \%$ of students agree that the site helps them understand the concept because it contains interactive videos and simulations. Finally, discovery learning using private sites improved student learning outcomes with a normalized gain score of 0.63 in the average category.

Web-based physics learning media using Google Sites should be developed again on other physics materials (Ismawati et al. 2021). Then the importance of design development is on the writing aspect so that it is more interesting to be seen by site visitors. In the learning video section in development design, it should be noted that the video is not stored on Google Drive. This is so that the video can play smoothly. The learning media for temperature and heat using the web (Moodle) has been properly validated with an average validation result of $82 \%$ (Simanjuntak et al. 2021).

The application of web-based learning on temperature and heat material can significantly improve the understanding of concepts among students compared to conventional learning methods and get a positive response (Zulkarnaini 2018). This is also in line with Yunita's research (2016) which states that web-based learning (Edmodo) dramatically affects the achievement and understanding of students' concepts because students' learning motivation increases. Students' abilities can increase during webbased learning because students can open the material to be discussed before learning begins. So that students can understand in advance the material to be studied (Ma'rifah et al. 2016). Based on Yuniar's 
(2021) research regarding learning media development for informatics subjects, media based on Google Sites is appropriate for students to use. The development model used is the Lee and Owens model. According to Yuniar (2021), it is necessary to develop learning media based on Google Sites in other subjects. In addition, a learning strategy is needed by prioritizing the TPACK approach.

From some of these studies, no research has developed a media on the material of Heat and Temperature using Google Sites. Therefore, the researchers researched the development of web-based learning using Google Sites on physics material, namely Heat and Temperature. The developed media is expected to be used in classroom as an alternative learning media so that the the problem of the lack of variety of learning media in classroom can be solved.

\section{METHODS}

The research method used is the research and development method. The research and development model used is the 4D model, but only includes defining, designing, and developing stages/ At the development stages, a validation test by experts was carried out. The following is an explanation of the three steps:

\section{Define}

At this stage, a literature study is to assess the fundamental competencies of class XI. The essential competencies studied are analyzing the effect of heat and heat transfer which includes the thermal characteristics of a material, capacity, and heat conductivity in everyday life. And competency skills are to design and conduct experiments on the thermal characteristics of a material, primarily related to heat capacity and conductivity, along with the presentation of experimental results and their use. The materials can be learned on the website as text, animation, and video.

\section{Design}

Researchers pay attention to three aspects of the media at the design stage. This stage includes media usability, functionality, and visual communication. Researchers pay attention to three aspects of preparing the material, namely learning design, material content, and linguistic.

\section{Develop}

Researchers carried out the development stage of the application of Heat and Temperature using Google Sites. Before putting all the material into Google Sites, researchers made supporting learning videos so that Web-Based learning is text and more enjoyable with video. The validation test will be carried out to decide whether the developed media needs a revision or not. The instrument indicators used were adopted from Lukitaningrum (2016) regarding media feasibility instruments and material feasibility instruments.

\section{RESULT AND DISCUSSION}

\section{Web-Based Learning}

The result of this development is in the form of a Web-Based Learning using Google Sites in which there are the materials of Heat and Temperature for Grade XI. Users don't need an internet connection to use this learning media. The media can be accessed freely by anyone linked to the website. The initial view of the website will be directed to the home menu, which contains core competencies, basic competencies, learning objectives, and apperception of Heat and Temperature material. 
TABLE 1. The results of the developed media

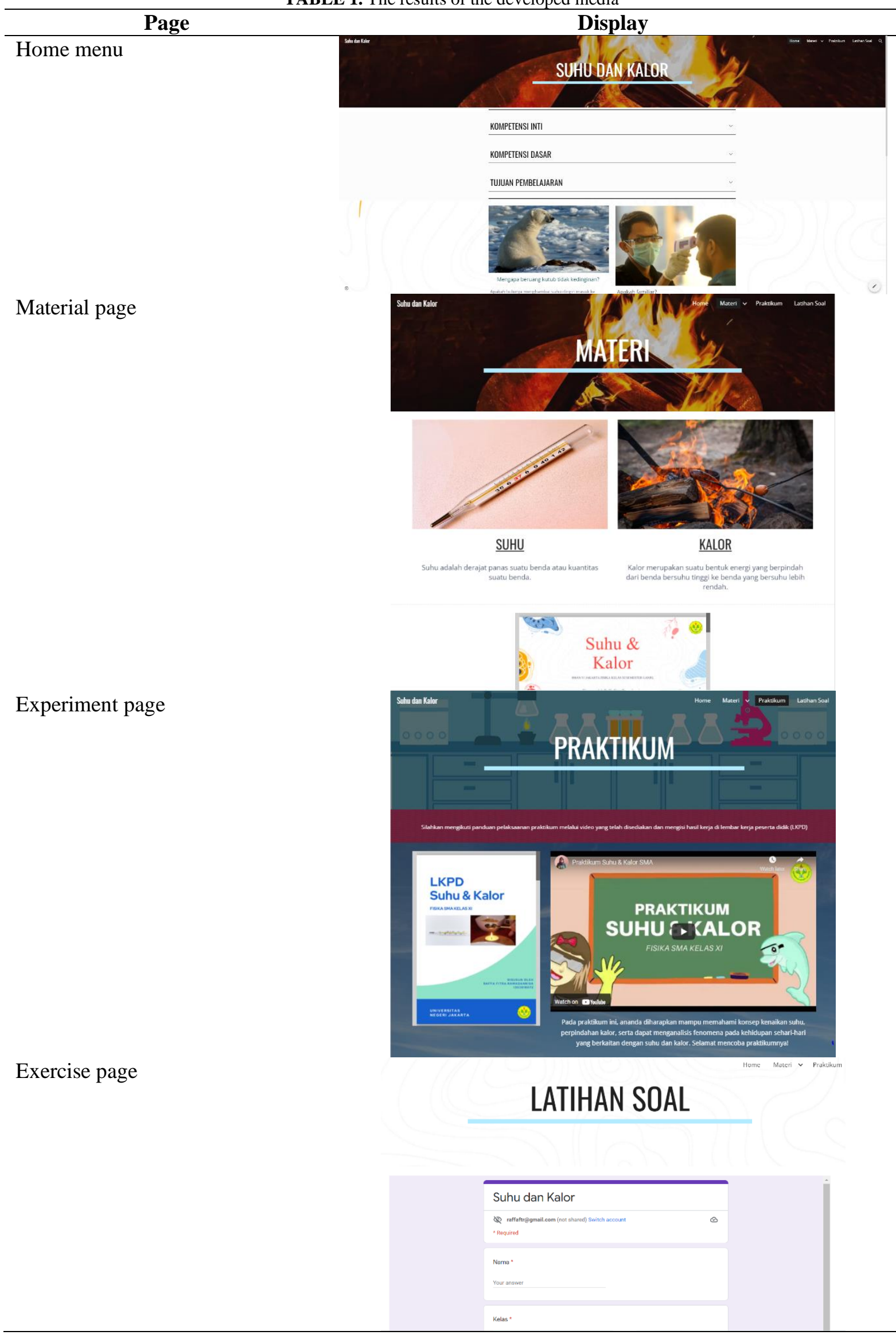


Students will start learning using the website on the "Material" section, which consists of two parts: heat and Temperature. The learning follows the syntax of Discovery Learning, where students find things out for themselves. Students also get to do simple experiments at home by following the guidance in the Experiment section. There will be a video tutorial on how to investigate and students' worksheets that should be filled after experimenting. The study was conducted with three meetings.

The developed Google Site media has been validated by media and materials experts. The results of the expert validation are presented in TABLE 2. Based on TABLE 2, the media and materials expert validation results indicate that the developed media is feasible with revisions for use in Grade XI High School Temperature and Heat learning.

TABLE 2. Validation results by experts

\begin{tabular}{cccc}
\hline No & \multicolumn{1}{c}{ Aspect } & Percentage & Interpretation \\
\hline \multicolumn{2}{c}{ Validation to Media Expert } & & \\
1 & Usability & $85 \%$ & Very feasible \\
2 & Functionality & $86.6 \%$ & Very feasible \\
3 & Visual Communication & $80 \%$ & Feasible \\
& Average & $83.8 \%$ & Very feasible \\
Validation to Material Expert & & \\
1 & Learning Design & $73.3 \%$ & Feasible \\
2 & Learning Content & $80 \%$ & Very feasible \\
3 & Linguistic & $80 \%$ & Very feasible \\
& Average & $77.7 \%$ & Feasible \\
\hline
\end{tabular}

The results of media validation by experts indicate that media use is very feasible, the buttons on the website also function well, the website design is also attractive and appropriate to use. The usability of the media gets a score of $85 \%$ with advice from experts, namely to provide more up-to-date information on the website. The website developed is declared to be easily accessible by experts. The functionality of the media gets a score of $86.6 \%$, which means that the navigation menu on the website is functioning properly and according to its use. Scores from practice questions will also be displayed immediately after students submit their answers. If the score obtained is still below the passing limit, students are asked to repeat the material presented. Visual communication from the media gets a score of $80 \%$, which means that the website design, such as selecting colors and fonts, is good.

While on material validation, the learning design got a lower score of $73.3 \%$. This is due to the lack of explanation of learning objectives on the website and the lack of relevance of learning objectives with essential competencies. In learning content and linguistics, the results are the same, namely $80 \%$.

According to Anggraeni and Sole (2018), e-learning can be used as a medium to improve the quality of interactive learning and support the implementation of face-to-face meetings in the classroom (blended learning). Through e-learning, Teachers and Students can access learning materials anytime and anywhere. Besides that, the material can be enriched with various learning resources, including multimedia. E-learning provides alternative solutions to educational problems, with functions adapted to needs, both as supplements, complements, and substitutions for learning activities. The online learning process using e-learning can train students to learn independently to switch to student-centered learning (Wahyudi 2017).

According to Mukti et al. (2020), web-based physics learning media using Google Sites can be used as a solution to make students interested in learning. With a design that can be arranged as attractively as possible and can be linked to other online facilities in the form of images, animations, videos, and even simulations, it is hoped that it can make students interested and motivated. The students that get the results that Google site makes students feel facilitated in the physics learning process and can help students in the learning process independently without a teacher. Ike's research (2021) also found that learning media using Google Sites on Sound Wave material got an average media validation score of $50.50 \%$ and material validation of $63.50 \%$. The two average score results are included in the "appropriate" criteria. In other words, this media, according to the experts, is feasible to be used and tested on students. Research by Bakri et al. (2021) shows that the e-learning model for problem-based learning in the Heat and Thermodynamics material was considered feasible. The e-learning model helps students think based on 21st-century learning demands, namely critical thinking, creativity, 
collaboration, and communication. Unfortunately, there are still very few collaboration facilities between students on this website, even though Google greatly facilitates collaboration with the Google Groups feature (Rambe 2017).

The lack of variety of learning media can cause problems. Teachers can overcome problems such as low learning motivation and student learning outcomes by developing learning media integrated with technology. Web-based learning media using Google Sites has been developed and equipped with video explanations of each material, supporting animations, worksheets, experiment videos, and practice questions. With the help of videos explaining the material, students can understand concepts that are still abstract. With the addition of experiment videos related to the material, students can do experiments at home independently and anywhere. However, further experiments related to temperature and heat are expected to teach critical thinking skills (Malik et al. 2019).

\section{CONCLUSION}

This research has produced web-based learning media using Google Site on Heat and Temperature material. In this development, the material is included in the website and equipped with a guided practicum using the provided video. Media experts have validated this medium with an average score of $83.8 \%$. At the same time, the average score of validation from material experts is $77.7 \%$. These results indicate that other researchers can still develop the Google Site's learning media on this Heat and Temperature material to make it more feasible to use. In further research, it is hoped that researchers can improve the quality of the material aspect so that teachers and students can use this media better. However, the results of this study indicate that the Google Site media on Heat and Temperature material is feasible to use. With this research, the media that has been developed is expected to be used by teachers in learning so that students' motivation, experience, and learning outcomes can increase.

\section{ACKNOWLEDGEMENT}

Researchers acknowledge and regards to the Directorate General of Higher Education which has provided fund for Talenta Inovasi 2021 Program so that this research can be carried out. We also send our biggest gratitude to our lecture, Mrs. Dewi Muliyati, who has helped and guided us in doing this research.

\section{REFERENCES}

Anderhag, P, Wickman, PO \& Hamza, KM 2015, 'How can teaching make a difference to students' interest in science? Including Bourdieuan field analysis', Cult Stud of Sci Educ, vol. 10, pp. 377 380.

Anggraeni, DM \& Sole, FB 2018, 'E-Learning Moodle, Media Pembelajaran Fisika Abad 21', Jurnal Penelitian dan Pengkajian Ilmu Pendidikan: e-Saintika, vol. 1, no. 2, pp. 57-65.

Azis, TN 2019, 'Strategi Pembelajaran Era Digital', The Annual Conference on Islamic Education and Social Science, vol. 1, no. 2, pp. 308-318.

Bakri, F, Sunaryo, S, Irawan, VF, \& Muliyati, D 2018, 'E-Learning Model for Problem Based Learning on Heat and Thermodynamic Topics in High School', Jurnal Penelitian \& Pengembangan Pendidikan Fisika, vol. 4, no. 2, pp. 101 - 112.

Halim, A, Mustafa, Nurulwati, Soewarno, \& Nanda, N 2018, 'Development Of Two-Tier Diagnostic Test Based On E-Learning', Journal of Physics: Conference Series, vol. 1120, p. 012030.

Ismawati, I, Mutia, N, Fitriani, N. \& Masturoh, S 2021, 'Pengembangan Media Pembelajaran Fisika Berbasis Web Menggunakan Google Sites Pada Materi Gelombang Bunyi', Jurnal Ilmiah Mahasiswa Pendidikan Fisika, vol. 2, no. 2. 
Januarisman, E \& Ghufron, A 2016, 'Pengembangan Media Pembelajaran Berbasis Web Mata Pelajaran Ilmu Pengetahuan Alam Untuk Siswa Kelas VII', Jurnal Inovasi Teknologi Pendidikan, vol. 3, no. 2, pp. 166-182.

Lisnaeni \& Salsabila, BZ 2021, 'Efektifitas E-Learning Fisika Berbasis Scientific pada Materi Elastisitas dan Hukum Hooke', Prosiding Seminar Nasional Aplikasi Sains \& Teknologi (SNAST).

Lukitaningrum, H 2016, 'Pengembangan Media Pembelajaran Berbasis Web Pada Materi Basis Data Di Sekolah Menengah Kejuruan Kelas XI', Skripsi, Universitas Negeri Yogyakarta.

Ma'rifah, E, Parno, P \& Mufti, N 2016, 'Dampak Strategi Dual Safeguard Web-Based Interactive (Dgwi) Dengan Model Problem Based Learning (Pbl) Terhadap Penguasaan Konsep Siswa Pada Materi Suhu Dan Kalor', Jurnal Pendidikan: Teori, Penelitian, \& Pengembangan, vol. 1, no. 7.

Mahendra, MR 2021, 'Development of Macromedia Flash-Based Mathematics Learning for Elementary School Student', Annual Conference on Science and Technology Research (ACOSTER) 2020, vol. 1783, p. 12006.

Malik, A., Novita, Y. \& Nuryantini, AY 2019, 'Enhancing Critical Thinking Skills of Students Related to Temperature and Heat Topics Through Problem Solving- Laboratory Model', Jurnal Penelitian \& Pengembangan Pendidikan Fisika, vol. 5, no. 1, pp. 9 - 20.

Mukti, WM, Puspita, YB, \& Anggraeni, ZD 2020, 'Media Pembelajaran Fisika Berbasis Web Menggunakan Google Sites pada Materi Listrik' Webinar Pendidikan Fisika: Optimalisasi Pendidikan dalam Rekontruksi Berbasis Sains dan Teknologi di Era New Normal. 14 November 2020.

Orooji, F \& Taghiyareh, F 2015, 'Supporting participants in web-based collaborative learning activities from a holistic point of view: a tale of seven online and blended courses', J. Comput. Educ. vol. 2, pp. 183-210.

Rambe, P 2017, 'Spaces for interactive engagement or technology for differential academic participation? Google Groups for collaborative learning at a South African University', J Comput High Educ, vol. 29, pp. 353-387.

Sarah LL 2021, 'The implementation of discovery learning using personal site in physics online classroom', Journal of Physics: Conference Series, vol. 1957.

Setyowati, R, Sarwanto, \& Muzzazinah 2021, 'How Students's Higher Order Thinking Skills through E-Learning during the Covid-19 Pandemic? What does it have to do with University?', IOP Conference Series: Earth and Environmental Science, vol. 1808.

Simanjuntak, MP, Manurung, AW \& Marpaung, N 2021, 'Desain Learning Management System Berbasis Moodle Dalam Pembelajaran Suhu dan Kalor', Proceeding Seminar Nasional IPA XI.

Taufik, M et al 2018, 'Pelatihan Media Pembelajaran Berbasis Web kepada Guru IPA SMP Kota Mataram', Jurnal Pendidikan dan Pengabdian Masyarakat, vol. 1, no. 1.

Wahyudi, I 2017, 'Pengembangan Program Pembelajaran Fisika SMA Berbasis E-Learning dengan Schoology', Jurnal Ilmiah Pendidikan Fisika, vol. 6, no. 2.

Wiwin, E, Kustijono, R \& Hakim, SR 2019, 'The effectiveness of scientific approach through the website in physics learning process at vocational high school', Journal of Physics: Conference Series, vol. 1171.

Yuniar AR, Subandowo, M, \& Karyono, H 2021, 'Pengembangan Bahan Ajar Informatika Berbasis Google Site Custome Domain', Jurnal Ilmiah Penelitian dan Pembelajaran Informatika, vol. 6, no. 2.

Yunita, L 2017, 'Efektifitas Problem Based Learning Berbantuan Edmodo Untuk Meningkatkan Prestasi Belajar Fisika Studi Pada Suhu Dan Kalor Kelas X Teknik Kendaraan Ringan SMK Tunas Bangsa Wanareja', Prosiding Seminar Nasional XI Rekayasa Teknologi Industri dan Informasi 2016 Sekolah Tinggi Teknologi Nasional Yogyakarta. 
Zulkarnaini, Z 2018, 'Penerapan Pembelajaran Berbasis Web untuk Meningkatkan Pemahaman Konsep dan Keterampilan Generik Sains Siswa Kelas X SMA pada Materi Suhu dan Kalor', Jurnal Dedikasi Pendidikan, vol. 2, no. 2, pp. 141-152. 